\title{
Germany holds up cultivation of GM maize...
}

Munich

The German government last week unexpectedly stepped in to block the commercial cultivation of genetically modified (GM) $\mathrm{Bt}$ maize by the biotechnology company Novartis. Citing the need to respect the 'precautionary principle', it is calling for more research into its potential hazards.

The ministers of health, agriculture, environment and research jointly called for a moratorium on the commercial growth of the maize - which has been genetically modified to express insecticidal toxins from the bacterium Bacillus thuringiensis - only one day before it was expected to be approved by the ministry of agriculture's Office for Varieties.

Health minister and Green Party member Andrea Fischer instructed the Robert Koch Institute in Berlin, the health ministry's office that licenses field trials, to revoke a licence it had issued to Novartis three years ago. Fischer argued that issues related to the crop's safety have not been resolved.

A report commissioned by Fischer from the Öko Institut, an independent environmental research institute in Freiburg known for its critical stance towards agricultural biotechnology, said it "could not be ruled out" that an antibiotic-resistance marker in the $B t$ maize gene construct would spread antibiotic resistance to the environment. The precautionary principle "must apply", she said. "More research needs to be done."

As a result of the government's move, the Office for Varieties has now put on hold its decision on licensing Novartis's Bt maize as a

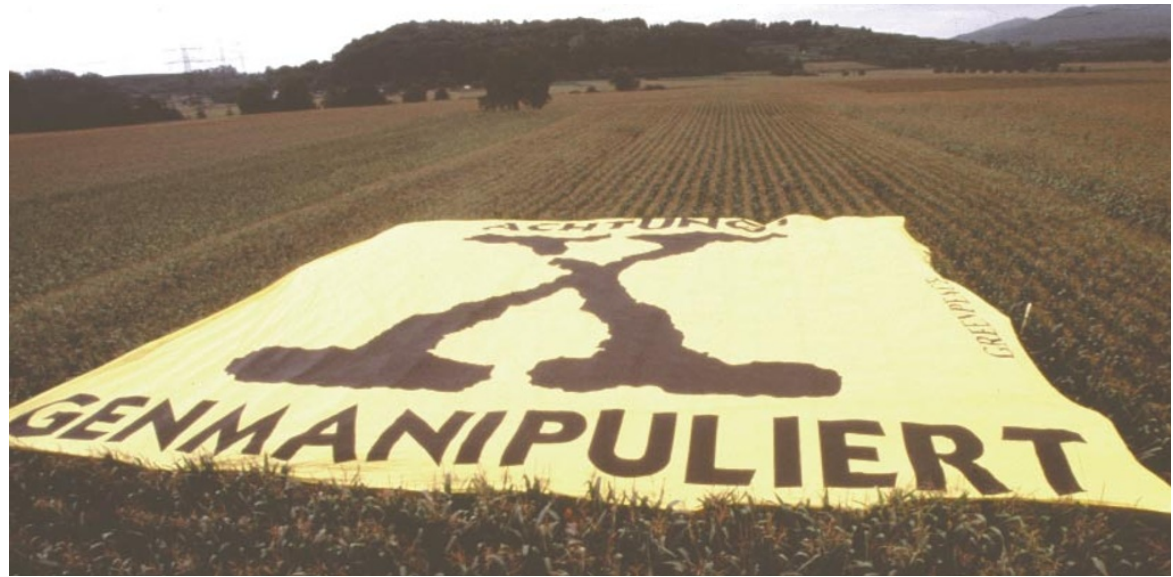

Genetic marker: Greenpeace campaigns have kept GM maize on the political agenda in Germany.

new variety. Such a licence is required for any new plant variety that is to be cultivated on a large scale.

Environmental groups, including Greenpeace and the German group BUND, have welcomed the decision. But the Organization of German Plant Breeders calls it "legally doubtful and politically questionable”.

The German Association of Biotechnology Industries calls it a "depressing decision from the government for the whole of the biotechnology industry". Novartis says it has not decided whether to fight the decision.

The German government's move is in line with the European Commission's de facto moratorium on licensing the commercial planting of GM plants.

However, the cultivation and commercialization of the $\mathrm{Bt}$ maize within the Euro-

\section{... amid calls for international biotech panel}

\section{London}

Proposals to create an international panel to study the scientific basis of the potential dangers of genetically modified (GM) crops - comparable to that which already exists for climate change - could emerge from an intergovernmental meeting to be held in Edinburgh next week.

The invitation-only meeting will involve about 400 scientists, politicians, policy-makers and non-governmental organizations. It has been organized by the Paris-based Organization for Economic Cooperation and Development at the request of heads of the so-called G8 group of industrialized nations, in particular the French president Jacques
Chirac, under the title 'GM Food Safety: Facts, Uncertainties and Assessment'.

Sir John Krebs, chairman of the conference and recently appointed head of Britain's Food Standards Agency, says that one idea put forward by "a number of people" is an international forum for debating scientific issues, like the International Panel on Climate Change.

"If one went forward with a panel that looked at the science one would want it to be a scientifically focused forum, but also to recognize that one would then have to fold in value systems beliefs, economic implications, and so on," says Krebs, who is also professor of zoology at the
University of $0 x f o r d$.

Krebs says that the main purpose of the meeting is to identify, through dialogue between individuals and groups with different, and often opposing, ideas, "areas of greater convergence and areas of lesser convergence".

"What we have seen in the past few years is a slanging match. I would hope that this might trigger a long-term process by which other matters related to trade and the environment can be debated in an open way," says Krebs.

A report on the Edinburgh meeting is due to be delivered when the G8 industrialized nations next meet. David Dickson pean Union had been authorized in 1997 under rules laid down in a $1991 \mathrm{EU}$ directive.

This authorization has been challenged by some countries. Last year Austria, with the support of Italy and Luxembourg, invoked a clause in the directive allowing authorization to be temporarily suspended at a national level if a member state claimed to have new evidence on safety.

Austria cited health and environmental concerns, particularly fears that the antibioticresistance marker in the $B t$ maize gene construct could spread resistance to humans or animals via gut bacterial flora.

The European Commission's scientific advisory committee rejected Austria's evidence on the grounds that it presented no new data. But it has not prosecuted Austria for flouting the directive, given the public's lack of acceptance of GM crops and food.

The Robert Koch Institute is preparing a report for the commission's scientific advisory committee citing similar concerns.

Officials informally admit that the report is unlikely to bring up new facts, other than research results published last December showing that insecticidal concentrations of $B t$ toxin are released into the soil from the roots of Btmaize (see Nature 402, 480; 1999).

The European Commission is hoping that revisions to its directive, under which authorizations for GM crops would in future be given for only ten years, with continual monitoring for environmental effects, will calm public concerns. The second reading of the revised directive is scheduled for April.

Hans-Günther Gassen, professor of biochemistry at the University of Darmstadt, and spokesman for biotechnology in the science committee of the state of Hessen's ministry of trade, says it is "very difficult to have effective, non-emotional dialogue with the public about agricultural biotechnology, particularly in Germany". His own institute was set on fire by an anti-biotechnology protest group in 1990.

Alison Abbot 